\title{
Review
}

\section{Genes: Roles in Development and Cancer}

\author{
Yinfei Tan ${ }^{1, *}$ and Joseph R. Testa ${ }^{1,2, *(\text { D }}$ \\ 1 Genomics Facility, Fox Chase Cancer Center, Philadelphia, PA 19111, USA \\ 2 Cancer Signaling and Epigenetics Program, Fox Chase Cancer Center, Philadelphia, PA 19111, USA \\ * Correspondence: Yinfei.Tan@fccc.edu (Y.T.); Joseph.Testa@fccc.edu (J.R.T.)
}

check for

updates

Citation: Tan, Y.; Testa, J.R. DLX Genes: Roles in Development and Cancer. Cancers 2021, 13, 3005. https: / / doi.org/10.3390/ cancers13123005

Academic Editor: Stefan Nagel

Received: 15 April 2021

Accepted: 11 June 2021

Published: 15 June 2021

Publisher's Note: MDPI stays neutral with regard to jurisdictional claims in published maps and institutional affiliations.

\section{Copyright: (c) 2021 by the authors.} Licensee MDPI, Basel, Switzerland. This article is an open access article distributed under the terms and conditions of the Creative Commons Attribution (CC BY) license (https:// creativecommons.org/licenses/by/ $4.0 /)$.
Simple Summary: DLX homeobox family genes encode transcription factors that have indispensable roles in embryonic and postnatal development. These genes are critically linked to the morphogenesis of craniofacial structures, branchial arches, forebrain, and sensory organs. DLX genes are also involved in postnatal homeostasis, particularly hematopoiesis and, when dysregulated, oncogenesis. DLX1/2, DLX3/4, and DLX5/6 exist as bigenes on different chromosomes, sharing intergenic enhancers between gene pairs, which allows orchestrated spatiotemporal expression. Genomic alterations of human $D L X$ gene enhancers or coding sequences result in congenital disorders such as split-hand/foot malformation. Aberrant postnatal expression of DLX genes is associated with hematological malignancies, including leukemias and lymphomas. In several mouse models of T-cell lymphoma, $D l x 5$ has been shown to act as an oncogene by cooperating with activated Akt, Notch1/3, and/or Wnt to drive tumor formation. In humans, DLX5 is aberrantly expressed in lung and ovarian carcinomas and holds promise as a therapeutic target.

Abstract: Homeobox genes control body patterning and cell-fate decisions during development. The homeobox genes consist of many families, only some of which have been investigated regarding a possible role in tumorigenesis. Dysregulation of HOX family genes have been widely implicated in cancer etiology. DLX homeobox genes, which belong to the NK-like family, exert dual roles in development and cancer. The DLX genes are the key transcription factors involved in regulating the development of craniofacial structures in vertebrates. The three DLX bigenes have overlapping expression in the branchial arches. Disruption of DLX function has destructive consequences in organogenesis and is associated with certain congenital disorders in humans. The role of DLX genes in oncogenesis is only beginning to emerge. DLX2 diminishes cellular senescence by regulating p53 function, whereas DLX4 has been associated with metastasis in breast cancer. In human ovarian cancer cells, DLX5 is essential for regulating AKT signaling, thereby promoting cell proliferation and survival. We previously implicated $D l x 5$ as an oncogene in murine T-cell lymphoma driven by a constitutively active form of $A k t 2$. In this mouse model, overexpression of $D l x 5$ was caused by a chromosomal rearrangement that juxtaposed the Tcr-beta promoter region near the Dlx 5 locus. Moreover, transgenic mice overexpressing $D l x 5$, specifically in immature T-cells, develop spontaneous thymic lymphomas. Oncogenesis in this mouse model involves binding of Dlx5 to the Notch1 and Notch3 gene loci to activate their transcription. Dlx5 also cooperates with Akt signaling to accelerate lymphomagenesis by activating Wnt signaling. We also discuss the fact that human DLX5 is aberrantly expressed in several human malignancies.

Keywords: homeobox genes; HOX; DLX; hematopoiesis; development; cancer; lymphoma; leukemia; Aka

\section{Introduction}

Homeobox genes were discovered more than three decades ago. They include a large group of genes that are essential in the development of multicellular organisms of the Metazoan division of the animal kingdom [1]. Cancer is often deemed as development gone awry. While some homeobox genes have oncogenic functions, others exert an opposite 
role. Homeobox genes have been categorized into 11 gene classes, which have been further categorized into many families during evolution [2,3]. The homeobox motif is a 180-bp DNA sequence encoding the homeodomain, which is highly conserved [4]. The protein product contains the homeodomain composed of helices in which helices II and III form helix-turn-helix (HTH) motifs [5]. This structure permits homeodomain proteins to bind to specific DNA consensus sequences and function as transcription factors [6]. Drosophila contains clustered NK-related homeobox genes, and these genes possess homeobox sequences of the ANTP class [7]. The vertebrate NK-like homeobox genes have essential roles in development and cancer [8]. The NKL class is subdivided into many gene families, such as NKX, NANOG, MSX, TLX, and DLX families [9]. While NKX, TLX, and MSX family genes have been implicated in T-cell acute lymphoblastic leukemia (T-ALL), the role of the DLX family has been less well studied in cancer [10].

\section{Structure and Origin of the $D L X$ Gene Clusters}

The DLX genes are homologs of Drosophila Distal-less (Dll), which was initially found to be specifically expressed in developing limbs [11]. DLX genes are now also known to be involved in the morphogenesis of branchial arches, forebrain, and sensory organs [12]. $D L X$ genes are comprised of six members in both human and mouse. Interestingly, DLX1/2, $D L X 3 / 4$, and DLX5/6 occur as bigene clusters in the genome on different chromosomes, by sharing intergenic enhancers between two genes, which allow orchestrated spatiotemporal expression [13-15]. For example, in mice, Dlx1 and Dlx2 are located on chromosome 2 at $42.61 \mathrm{cM}$ and $42.65 \mathrm{cM}$, respectively, Dlx3 and Dlx4 are located on chromosome 11 at $59.01 \mathrm{cM}$, and Dlx 5 and Dlx 6 are located on chromosome 6 at $2.83 \mathrm{cM}$. Each of the gene pairs has one gene located in the plus (+) strand and one on the minus (-) strand in a tail-to-tail orientation. The $D l x 1 / 2$ bigene is linked to the HoxD cluster on chromosome 2, with intergenic enhancer elements i12a and i12b [16]. The Dlx3/4 bigene is linked to the HoxB cluster on mouse chromosome 11 , with five intergenic cis elements $[17,18]$. The $D l x 5 / 6$ bigene is associated with the HoxA cluster on chromosome 6, with i56a/b (or i56i/ii) as the intergenic enhancer [19-21] (Figure 1). The intergenic enhancer plays a major role in regulating the expression of $D l x 5 / 6$. The mi56i-Cre transgenic mice exhibit the same expression pattern of Cre in the R26R strain as those of endogenous Dlx5 and Dlx6 in the facial skeleton and specific brain structures in term embryos [22].

The gene pairs orient in a tail-to-tail arrangement with the enhancer in between. It is hypothesized that these three $D l x$ clusters could be duplicates of an ancestral $D l x$ pair, which may have occurred during evolution, with the first gene pair being the result of a tandem gene duplication $[23,24]$. The expression patterns are similar among these gene pairs, although the $D l x 1 / 2$ enhancer (I12a/b) has little similarity to that of $D l x 5 / 6$ (I5i, I56ii). However, these enhancers have been conserved across species. The Dlx1/2 enhancer has greater than $75 \%$ homology among humans, mice, and zebrafish. Likewise, the Dlx5/6 enhancer shares more than $80 \%$ similarity among these three species [16]. The homeoboxes of the various Dlx genes are highly homologous, suggesting they may have somewhat redundant roles. 

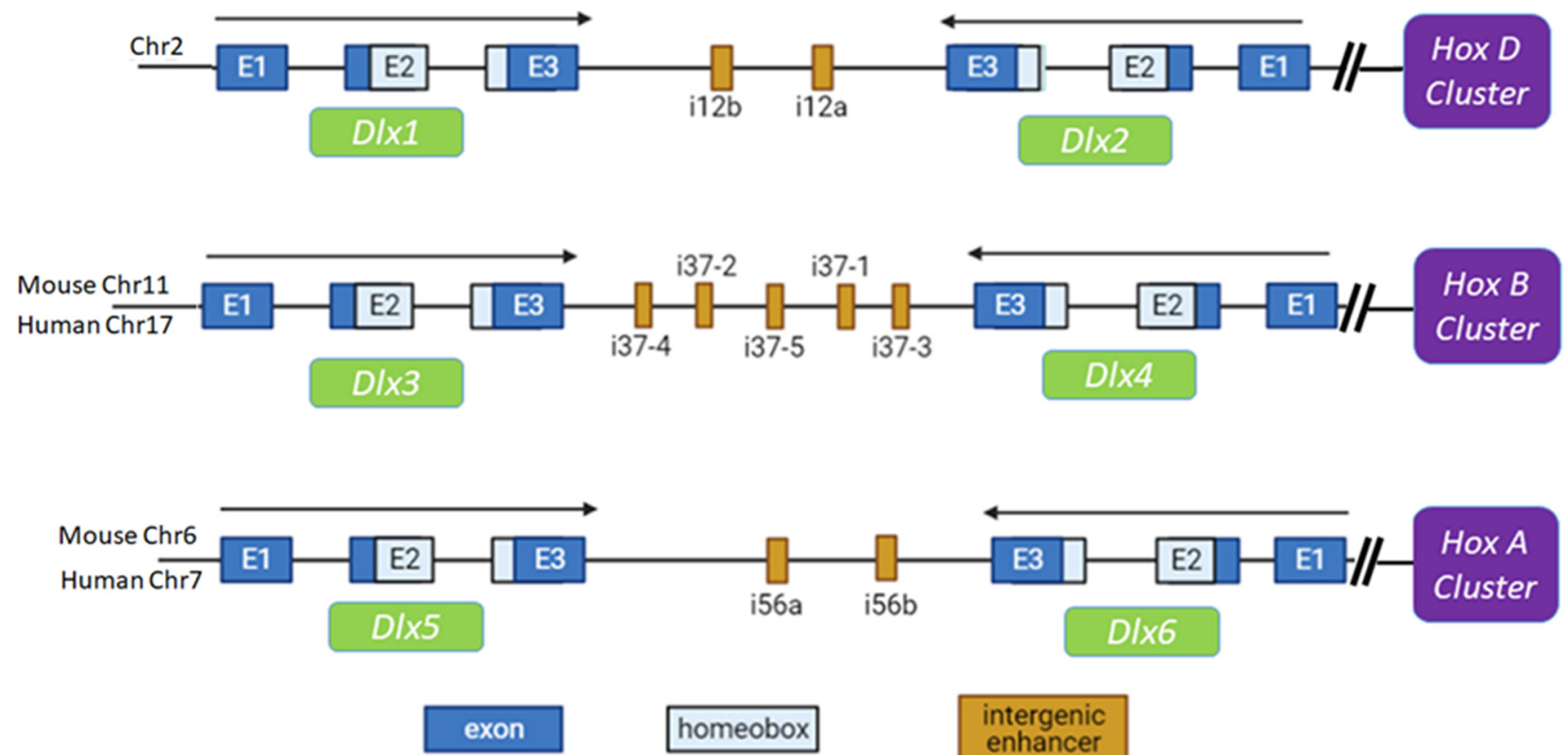

Figure 1. Structure of mouse and human $D l x$ gene family. The $D l x$ genes are comprised of three exons. The homeobox motif (light blue) resides within part of Exon2 and Exon3. The Dlx1/2 bigene is linked to the HoxD cluster on chromosome 2 in both human and mouse, with intergenic enhancer elements i12a and i12b. The $D l x 3 / 4$ bigene is linked to the HoxB cluster on mouse chromosome 11, with five intergenic cis elements. The Dlx5/6 bigene resides along with the HoxA cluster on chromosome 6, with i56a/b (or i56i/ii) as the intergenic enhancer.

\section{Dlx Genes in Normal and Aberrant Development}

$D l x$ gene family members have indispensable roles in embryonic morphogenesis and postnatal development. Disturbances in the regulatory mechanisms of $D l x$ gene expression or function result in severe consequences. $D l x 1$ and $D l x 2$ are expressed in the proximal and distal first and second arches. Mutations of $D l x 1$ or $D l x 2$ alter the proximodistal patterning of the branchial arches, suggesting that $D l x 1$ and $D l x 2$ have overlapping roles in craniofacial development [25]. Knockout of $D l x 1$ or $D l x 2$ alone results in abnormalities of the forebrain, and homozygous knockout mice have been shown to die prematurely or at birth [26]. Dlx1/Dlx2 double mutant mice were found to have defects in the striatal subventricular zone and differentiation of late born striatal neurons [27]. Dlx gene members have also been implicated in the morphogenesis of eyes, nose, ears, and teeth. Dlx1/2 is essential for the formation of the retina, and the absence of $D l x 1 / 2$ results in the apoptosis of retinal ganglion cells and a diminished ganglion cell layer [28], and new born mice were unable to survive with this defect [27]. Interestingly, Dlx5 and Dlx6 are also expressed in the developing forebrain. $D l x 1$ and $D l x 2$ can bind to the intergenic enhancer of $D l x 5 / 6$ and regulates the expression of this bigene. Consequently, expression of $D l \times 5 / 6$ was downregulated in $D l \times 1 / 2$ double mutant mice [29].

The Dlx 5 gene is expressed in the branchial arches, restricted brain regions, extending appendages, and bones during embryogenesis. Dlx 5 knockout mice die shortly after birth, suffering from craniofacial abnormalities and malformations of the vestibular organ [30]. The craniofacial abnormalities include exencephaly, hypoplastic nasal capsules, and dysmorphic proximal mandibular arch skeleton [12]. In addition to those same defects, $D l x 5 / 6$ double knockout mice exhibit a novel defect in limb development known as split-hand/split-foot malformation (SHFM). However, the spatiotemporal-specific overexpression of the $D l x 5$ gene, in the apical ectodermal ridge of $D l x 5 / 6$-null mice can rescue this limb malformation, indicating that $D l x 5$ and $D l x 6$ have redundant roles [31]. The craniofacial and limb defects in $D l x 5$ knockout and $D l x 5 / 6$ double knockout mice are potentially due to defects in osteoblast maturation [32]. Dlx5 and Dlx6 also play a role in the developing 
vestibular apparatus. Dlx5/6-null embryos have otic induction, but cannot form dorsal otic derivatives [33]. The orchestrated expression of $D l x 1 / 2, D l \times 3$, and $D l x 6$ are essential for control of enamel formation via direct regulation of ameloblast differentiation [34].

$D l x 5$ and Dlx6 also play a role in testis development. In fetal Leydig cells, Dlx5 transcriptionally activates the steroidogenic acute regulatory protein gene (STAR) via GATA-4, thereby, regulating steroidogenesis [35]. Despite the essential function of $D l x$ genes in craniofacial development, their regulatory mechanism is not well defined. Interestingly, a MADS-box transcription factor $M E F 2 C$, which is a key to cardiac morphogenesis, vascular development, and myogenesis, controls the expression of $D l \times 5 / 6$ in the branchial arches [36] (Figure 2). Moreover, Tp63 is also involved in limb development, and it can bind to the Dlx5/6 promoter. Tp63 knockout mice exhibit severe limb defects with reduced expression of $D l x$ genes [37]. In addition to the intergenic enhancer, there is an enhancer outside of the DLX5/6 bigene cluster. This new enhancer can drive the expression of a reporter gene in the inner ears and bones of transgenic mice. The deletion of this cis element on human chromosome 7 accounts for a familial syndrome involving hearing loss and craniofacial defects due to reduced expression of DLX5/6 [38]. P63 can also bind to the Dlx3 promoter [39]. Dlx3 regulates bone formation by controlling the expression of $D l x 5, D l x 6$, Runx2, and Sp7 [40] (Figure 2). Dlx2, Dlx5, and Dlx6 are expressed most strongly in less mature osteoblasts, whereas $D l x 3$ is very highly expressed in differentiated osteoblasts and osteocytes, suggesting that $D l \times 2$ and $D l \times 5 / 6$ can stimulate osteoblastic differentiation and that Dlx3 plays a discrete role in late-stage osteoblast differentiation [32]. The OSX zinc finger protein is a cofactor that binds to Dlx 5 to activate the osteoblast differentiation program, and the p53 tumor suppressor can suppress this program by competitive binding to OSX, which thereby diminishes Dlx 5 function [41]. Such differentiation can be suppressed by p53. Human DLX proteins play an important role in bone development, and disruption of DLX function underlies the etiology of certain bone/joint diseases. For example, a 4-bp deletion of the DLX3 gene has been reported in families with tricho-dento-osseous syndrome (TDO), which is characterized by abnormalities involving hair, teeth, and bone development. Transgenic mice harboring such a deletion demonstrated enhanced trabecular bone volume and mineral density, suggesting a novel role for Dlx3 in osteoclast differentiation and bone resorption [42].

$D l x 4$ is expressed in the mesenchyme of murine palatal shelves during embryonic development, and a specific mutation in DLX4 (c.546delG) causes familiar cleft lip and/or palate [43]. Macrodactyly is a congenital disease characterized by overgrowth of soft tissues and bones. RNA-seq analysis has revealed that DLX5 is upregulated by an activating mutation in the phosphatidylinositol 3-kinase, catalytic alpha gene (PIK3CA) in macrodactyly-derived bone marrow mesenchymal stem cells (BMSCs), implying that DLX5 has contributes to bone overgrowth due to constitutive PI3K/AKT signaling [44]. DLX also has a role in chondrocyte proliferation. Chondrocyte hypertrophy is a hallmark of osteoarthritis (OA) pathology. Knockdown of Dlx 5 in BMSCs reduced cell hypertrophy and apoptosis. Overexpression of DLX5 in human-cartilage-derived mesenchymal progenitors increased the expression of hypertrophy markers and enhanced apoptosis, suggesting that DLX5 is a biomarker of OA changes in human knee joint tissues by contributing to hypertrophy and apoptosis in BMSCs [45]. Utilizing the regulatory features of DLX transcription factors has practical applications. For example, recently DLX was found be able to reprogram somatic cells into induced pluripotent stem cells (iPSCs), with DLX4 being able to functionally replace c-MYC to support efficient reprogramming of human dental pulp cells, in combination with OCT3/4, SOX,2 and KLF4 [46]. 


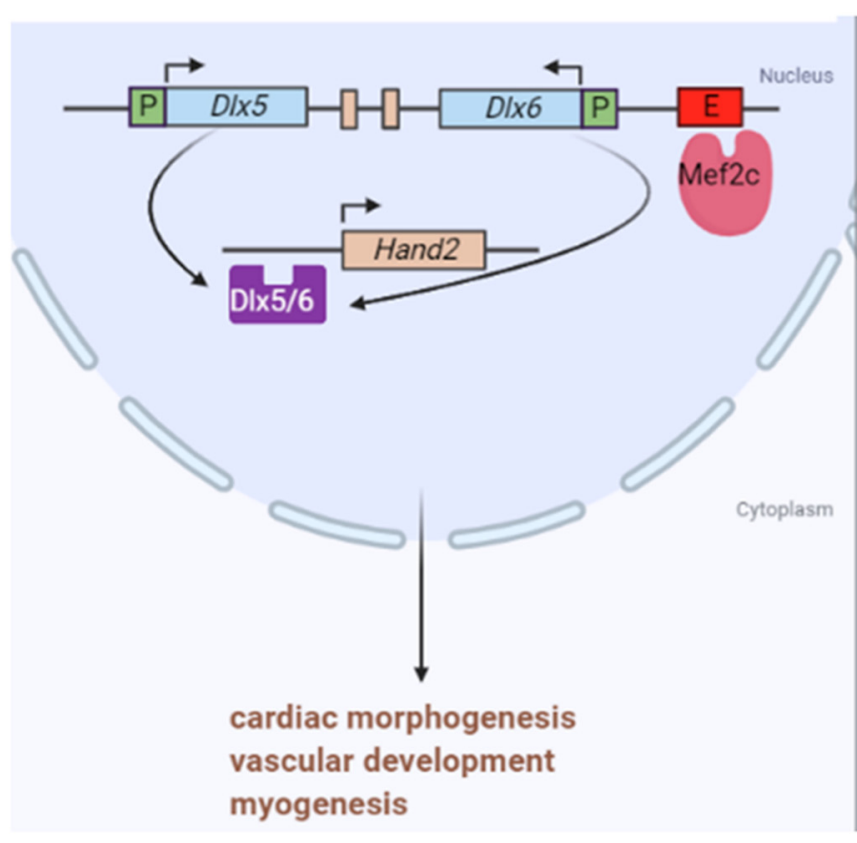

(A)

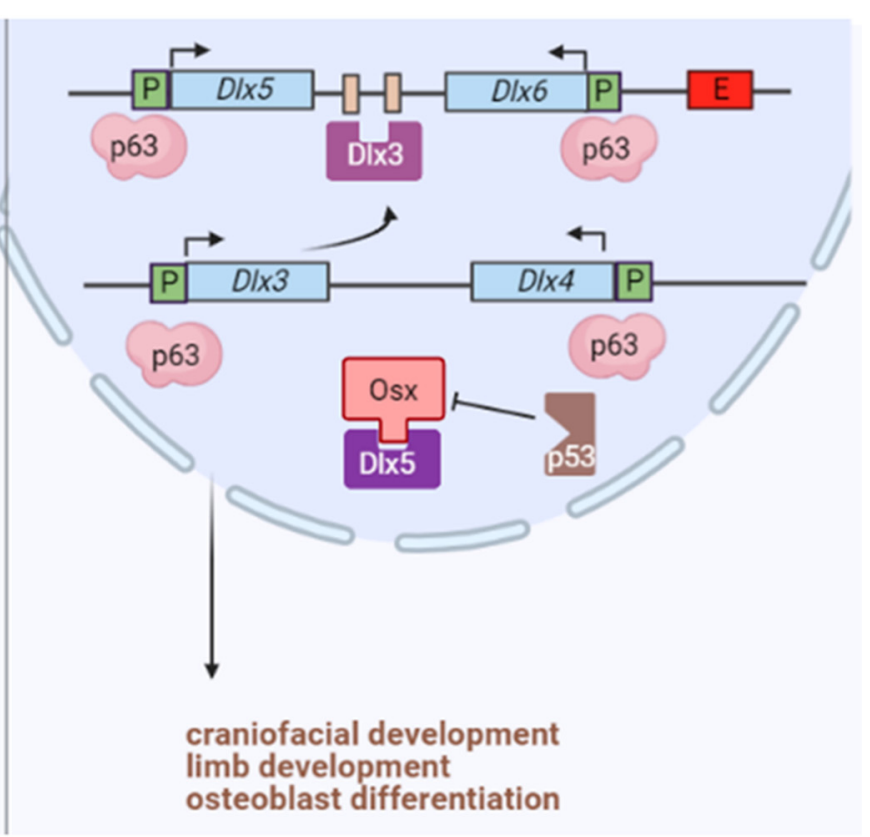

(B)

Figure 2. Regulation of Dlx expression. (A) Mef2c binds to a novel enhancer (E) outside of the Dlx5/6 bigene. The Dlx5/6 product activates the Hand2 gene, which is essential for cardiac morphogenesis, vascular development, and myogenesis; (B) P63 transactivates $D l x 3 / 4$ as well as Dlx5/6 via binding to their promoters. Dlx3 can also regulate Dlx5/6 expression. Osx functions as a coactivator of Dlx5 in an osteogenic transcriptional network, whereas p53 binds to Osx to inhibit its role.

\section{DLX Genes in Normal Hematopoiesis}

Some transcription factors that are essential for the development of the nervous system are also involved in hematopoiesis. For example, Gata2 knockout mice have severe defects in neurogenesis as well as hematopoiesis [47]. Dlx genes have similar dual roles in neural and hematopoietic systems. For instance, $D l x$ genes have been found to be co-expressed with Bmp4 in some tissues during embryogenesis, and Bmp4 is a TGF- $\beta$ family member that plays an important role in the differentiation of early mesodermohematogenic cells and hematopoietic stem cells [48,49]. DLX1 interacts with SMAD4 via its homeobox domain, which interferes with the transactivation of SMAD4 (Figure 3). Thus, DLX1 can regulate the function of members of the TGF- $\beta$ family during hematopoiesis [50]. In the developing thymus, $D l x 1$ and $D l x 2$ have been detected in thymocytes from 13.5- and 16.5-day-old embryos. Although Dlx1 knockout mice did not have any discernable developmental defects in either the thymus or thymocyte development, expression of Dlx 1 in neural crest derivatives suggested a potential redundant role in cell migration/migration with other homeobox genes [51].

Actually, Dlx genes play a critical role in the development of a subtype of lymphocytes. In the bone marrow of adult mice, Dlx $1, D l \times 2$, and predominantly Dlx 3 are transiently expressed in immature Mac-1(lo) NK cells, whereas in mature splenic NK cells, such expression was abolished [52]. The persistent expression of $D l x$ genes leads to functionally immature NK cells arrested at the Mac-1(lo) stage. Moreover, persistent $D l x 1$ expression stalls the differentiation of T-cells and B-cells [52]. This occurs at least partially via the transactivating aryl hydrocarbon receptor (AhR), which is a transcription factor essential for the development of some immune cell subsets [53] (Figure 3). Another DLX family member, DLX4, is expressed in normal hematopoietic cells and human leukemia cell lines with erythroid characteristics. Antisense oligonucleotides targeting DLX4 have been shown to trigger apoptosis in the human erythroleukemia cell line K562, in connection with a reduction in GATA1 and MYC mRNA levels [54]. During megakaryopoiesis, DLX4 expression increases, but during erythropoiesis, it decreases. DLX4 induces IL1 $\beta$ production, 
which turns on NF- $\mathrm{KB}$ signaling and potentiates a megakaryocytic transcriptional program. Blocking NF- $\mathrm{kB}$ activity reverses this program toward differentiation into erythroid lineages [55] (Figure 3).

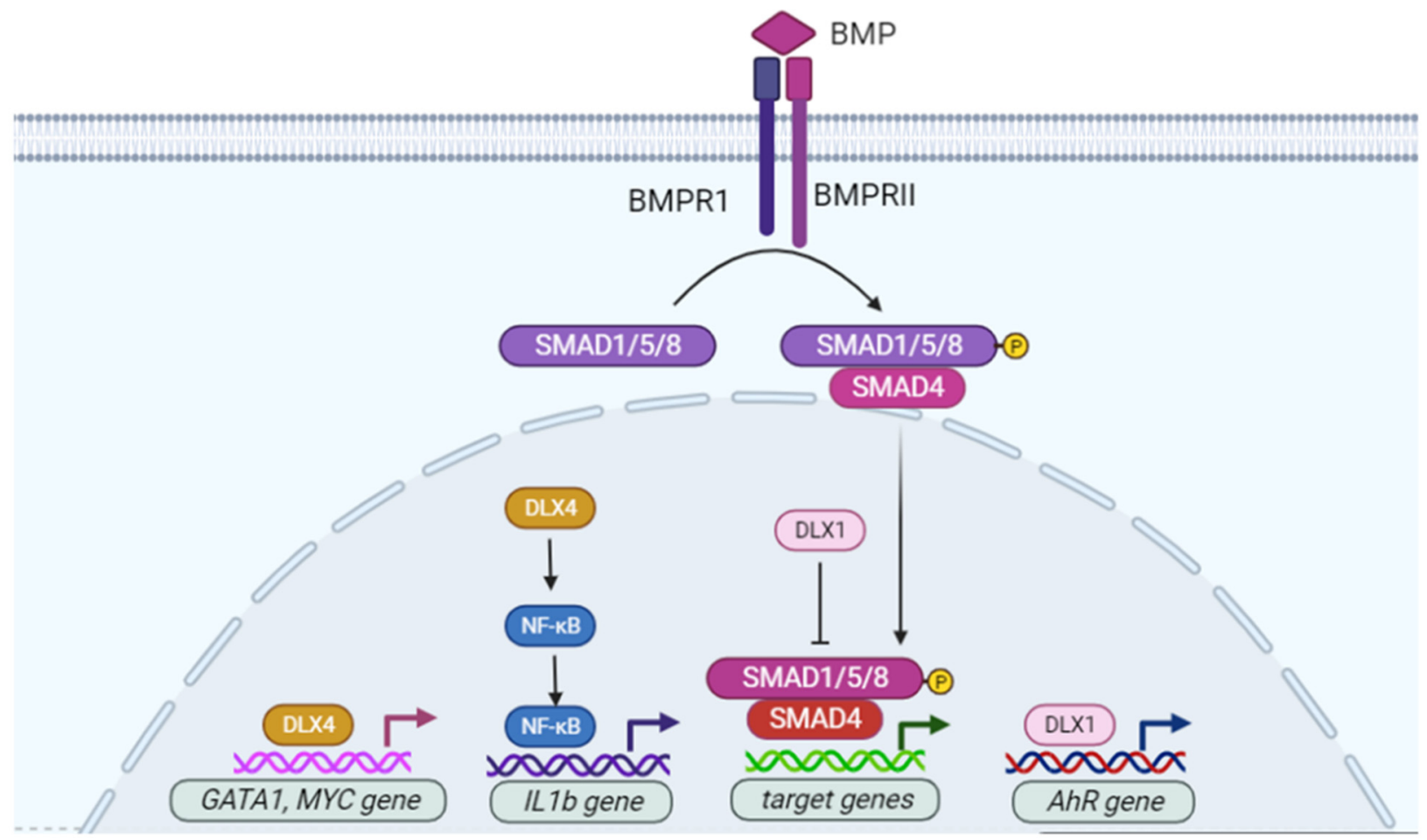

Figure 3. Role of DLX4 in hematopoiesis. DLX1 regulates BMP4 signaling via binding to SMAD4 and inhibiting its transactivation activity. DLX1 also directly regulates the expression of transactivating aryl hydrocarbon receptor (AhR) during T/B cell differentiation. DLX4 also enhances NF- $\mathrm{KB}$ signaling to promote IL1 $\beta$ production in a megakaryocytic transcriptional program. In addition, DLX4 has been shown to sustain the viability of K562 erythroleukemia cells by promoting the expression of GATA1 and MYC.

\section{DLX Genes in Aberrant Hematopoiesis}

T-cell acute lymphoid leukemia (T-ALL) is thought to originate from arrested T-cell progenitors during differentiation. Due largely to specific chromosomal rearrangements, the aberrant expression of certain NKL homeobox genes disrupt T-cell differentiation and give rise to T-ALL. However, the role of NKL homeobox genes is highly context dependent. For example, the MSX1 gene is normally expressed in common lymphoid progenitors $(C L P)$ and remains active in NK cells. Interestingly, MSX1 behaves as an oncogene in T-ALL but acts as a tumor suppressor gene in NK-cell leukemia [56,57]. Acute myeloid leukemia (AML) frequently has activating mutations in the FMS-like tyrosine kinase-3 gene (FLT3), which are a poor prognostic marker. Notably, DLX1/2 are downstream targets of aberrant FLT3 signaling via the MAPK pathway. Inhibition of FLT3 results in reduced levels of DLX1/2, which in turn enhances TGF- $\beta$ signaling [58]. In leukemic patients with the $\mathrm{t}(4 ; 11)(\mathrm{q} 21 ; \mathrm{q} 23)$ chromosomal translocation, which generates a MLL-AF4 fusion protein (now known as KMT2A-AFF1), the expression of DLX2, DLX3, and DLX4 was diminished; these findings indicate that intact MLL/KMT2A1 normally regulates the expression of these $D L X$ family members [59]. In pediatric B-ALL patients with a MLL-AF4 rearrangement, the DLX3 gene has aberrant CPG methylation, which results in reduced expression of DLX3; in contrast, patients with a TEL-AML1 rearrangement, which has a better prognosis, did not have such methylation [60]. Hypermethylation of the DLX5 gene occurs frequently in AML and myelodysplastic syndrome (MDS). Such silencing of DLX5 is associated with a lower rate of complete remission and poorer overall survival, suggesting a tumor suppressing role of DLX5 in AML and MDS [61]. 
Transgenic mice expressing a constitutive activation of the Akt2 oncogene specifically in immature T-cells, Lck-MyrAkt 2 mice, develop a high rate of spontaneous thymic lymphomas, including some founders that acquire a recurring chromosomal inversion that juxtaposes the enhancer of the T-cell receptor- $\beta$ (Tcrb) locus and the Dlx5/6 bigene, thereby, resulting in overexpression of Dlx5 and, to a lesser extent, Dlx6 [62] (Figure 4). Similar to other $D l x$ family members, mouse $D l x 5$ and human $D L X 5$ are not expressed in mature thymocytes [52,62]. However, DLX5 mRNA, but not DLX6 mRNA, was abundantly expressed in three of seven human T-cell lymphomas we tested [62]. Subsequent transgenic mouse experiments revealed that forced expression of Dlx5 in immature T-cells using a Lck promoter (Lck-Dlx5 mice), also induced thymic lymphomas [63]. Whole transcriptome analysis showed that these thymic lymphomas consistently showed upregulation of Notch1 and Notch3, and in vitro experiments revealed that these lymphoma cells were highly sensitive to Notch inhibitors [63]. Additionally, Dlx5 was found to directly bind to the regulatory elements of the Notch1 and Notch 3 genes, as revealed by ChIP-seq analysis (Figure 5), and Dlx5 was able to transactivate luciferase expression by binding to these elements in vitro [63].

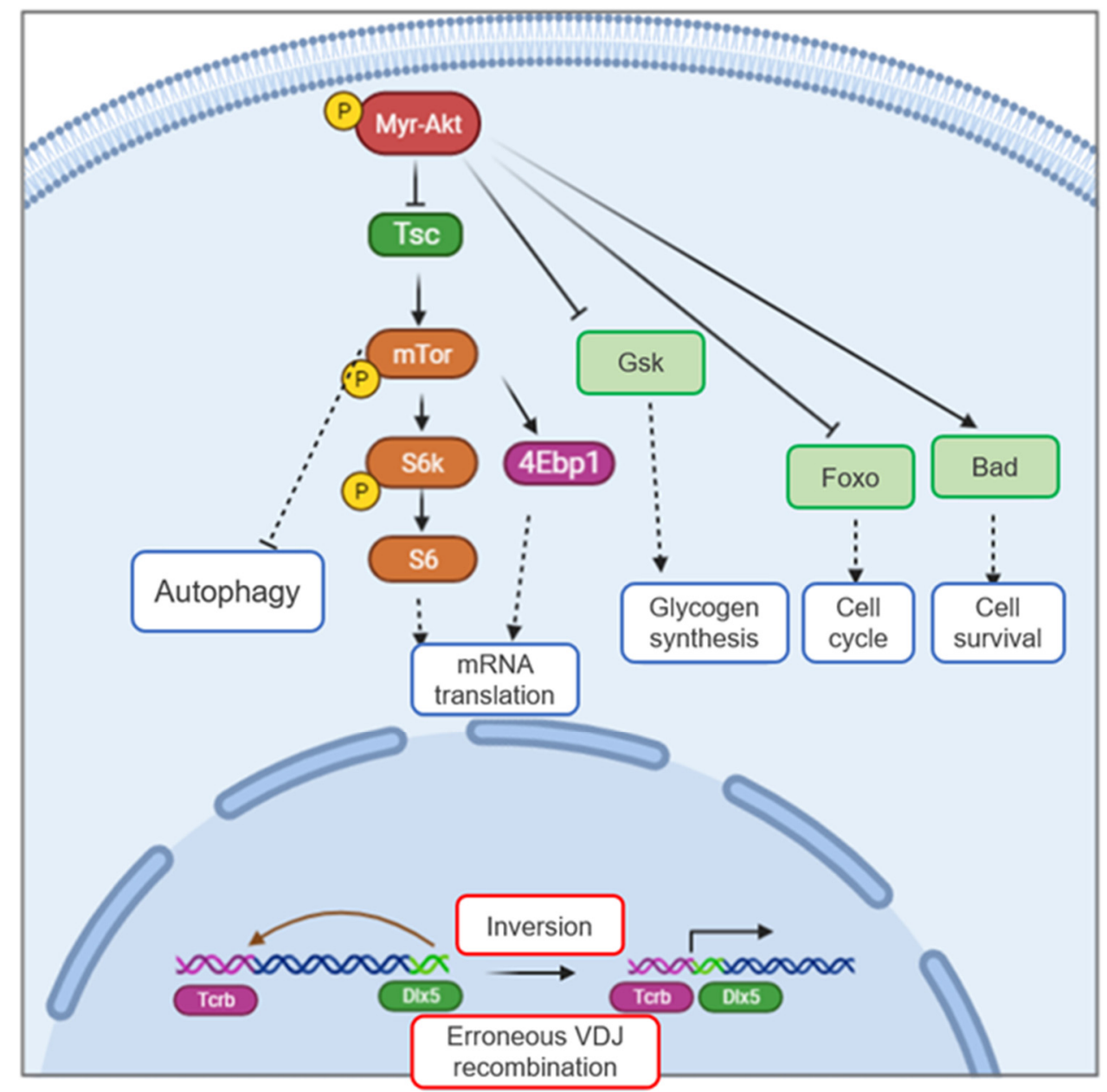

Figure 4. Activation of the Dlx5 gene triggers T-cell lymphoma. Expression of a constitutively activated form of $A k t 2$ (MyrAkt2) in immature mouse thymocytes induces T-cell lymphoma via activation of $D l x 5$ gene expression, due to a recurrent chromosome rearrangement with Tcrb. Constitutive activation of the Akt pathway promotes survival in cells that undergo aberrant $V D J$ rearrangement and would otherwise undergo apoptosis, whereas the acquisition of T-cell-specific overexpression of $D l x 5$ gene provides a proliferative advantage that, together, result in lymphomagenesis. 


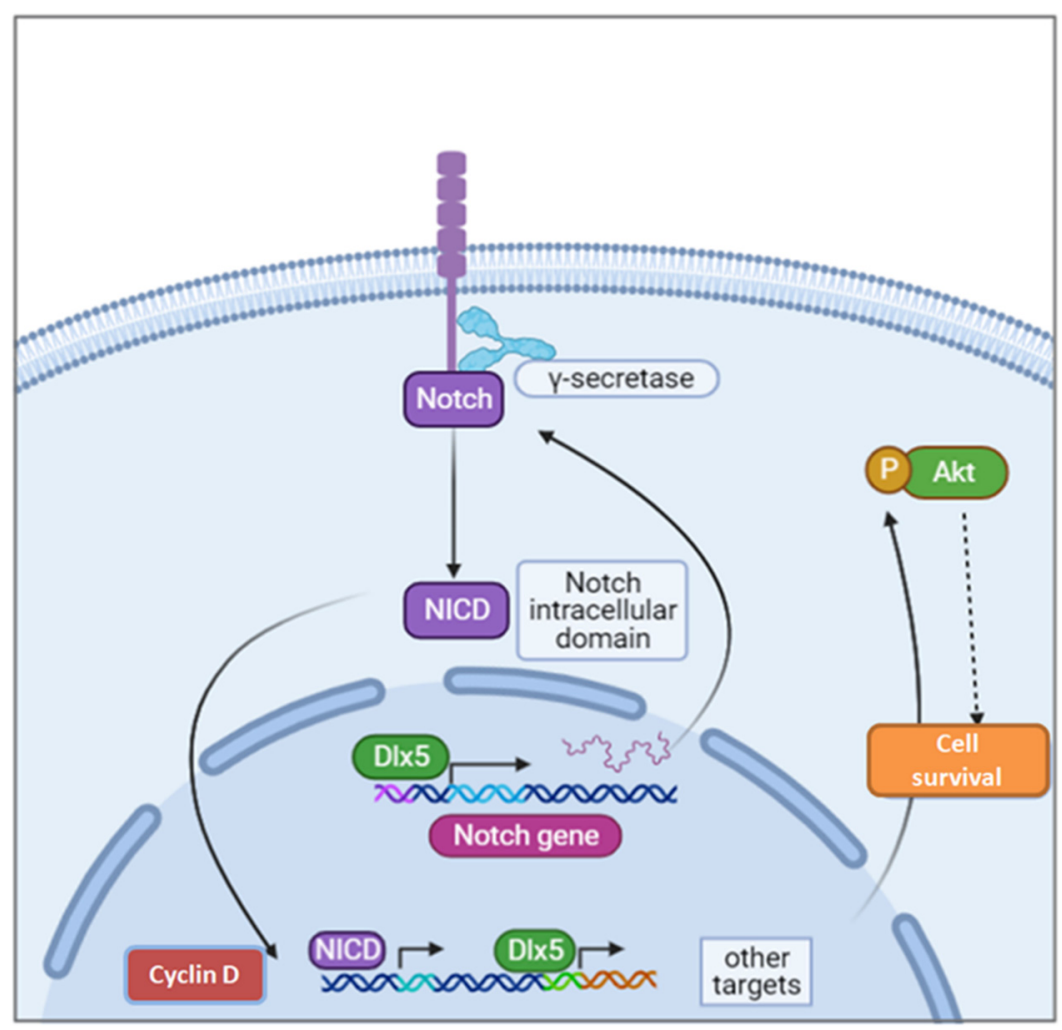

Figure 5. Dlx5 directly induces T-cell lymphoma by activating Notch. A transgenic mouse model expressing Dlx5 gene under the control of a Lck promoter develops a high incidence of T-cell lymphomas with overexpression of Notch genes, Notch1 and Notch3. These lymphoma cells were very sensitive to $\gamma$-secretase inhibitors and exhibited upregulation of Akt signaling and upregulation of Cyclin D.

Other NKL members such as MSX2, TLX1, and NKX2-5 can also upregulate Notch3 by interacting with NOTCH pathway repressors [10]. Moreover, Akt signaling and cMyc levels are consistently elevated in Dlx5-induced lymphomas, and pharmacological inhibition of Akt and c-Myc triggers these lymphoma cells to undergo apoptosis [64]. These observations suggests that prolonged expression of Dlx5 in progenitor T-cells trigger lymphomagenesis via the activation of oncogenic pathways commonly involved in $\mathrm{T}$ lymphomagenesis, including Notch, Myc, and Akt. On the one hand, activation of these signaling pathways promotes cell survival and inhibit apoptosis when Tcr rearrangements go awry. On the other hand, frequent upregulation of Wnt signaling has also been reported in pediatric T-ALL [65], and an activating mutation of the $\beta$-catenin gene, Ctnnb1, has been shown to induce T-ALL in mice without Notch upregulation [66]. The medium survival of these Ctnnb1-mutant mice was 14 weeks as compared with 24 weeks in LckMyrAkt 2 mice and 39 weeks in $L c k-D l x 5$ mice. This suggests that $C t n n b 1$ behaves as a strong oncogene in a T-cell transgene setting, whereas active Akt2 is less oncogenic, and Dlx5 is weakly oncogenic [67]. Interestingly, however, the median survival of Lck-MyrAkt2;Dlx5 double transgenic mice was 10 weeks, suggesting a synergistic effect between Akt and Dlx5 (Figure 6) [67]. This synergism is likely due to the fact that $\beta$-catenin is strongly expressed and resides in nucleus of the T-cell lymphomas from the Lck-MyrAkt2;Dlx5 double transgenic mice. 


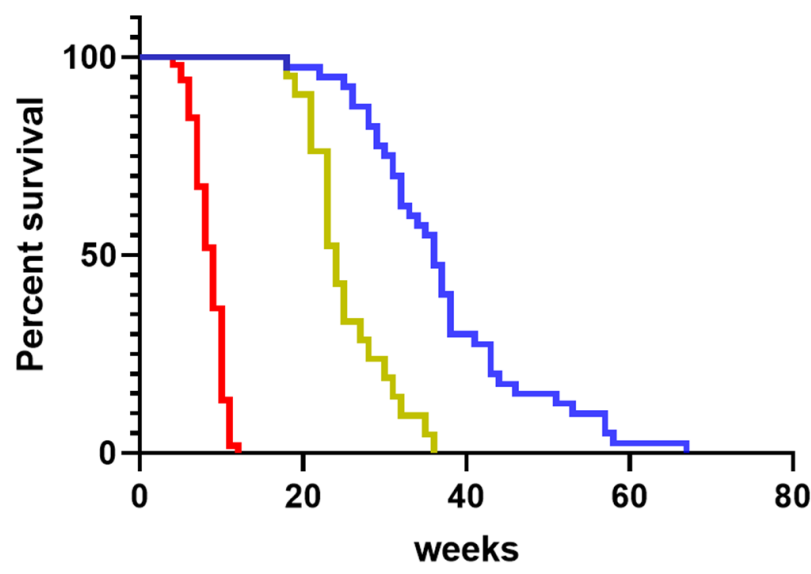

- Lck-DIx5

ᄂ Lck-Akt2

+ Lck-D/x5;Akt2

Figure 6. Survival curve of $L c k-D l x 5$ mice with T-cell lymphomas as compared with Lck-MyrAkt2 and double transgenic Lck-MyrAkt2; Dlx 5 mice. The median survival was 24 weeks in $L c k$-Dlx 5 mice, 39 weeks in Lck-MyrAkt2 mice, and 10 weeks in Lck-MyrAkt2;Dlx 5 mice.

Despite the multiple genes and pathways activated in these lymphomas, Wnt signaling appeared to be the key driver, because inhibition of the Wnt pathway triggered rapid cell death [67]. Whether Dlx 5 can directly bind to the Ctnnb1 locus to increase its expression when the cellular context is changed by the addition of Akt hyperactivation is an intriguing question. Further study by RNA-seq analysis has demonstrated that the cholesterol biosynthesis pathway is highly upregulated in lymphoma cells from Lck-MyrAkt2;Dlx5 mice. The $\beta$-catenin/Tcf complex directly binds to genes encoding key members of this pathway, such as Cyp51, Hmgcr, Ncoa2, Pmok, Sp1, Srebf1, Srebf2, Tbl1x, and Tbl1xr1. Moreover, statin and other cholesterol inhibitors were shown to effectively limit the proliferation of lymphoma cells from Lck-MyrAkt2;Dlx5 mice at low concentrations and cause cell death at higher concentrations [67] (Figure 7).

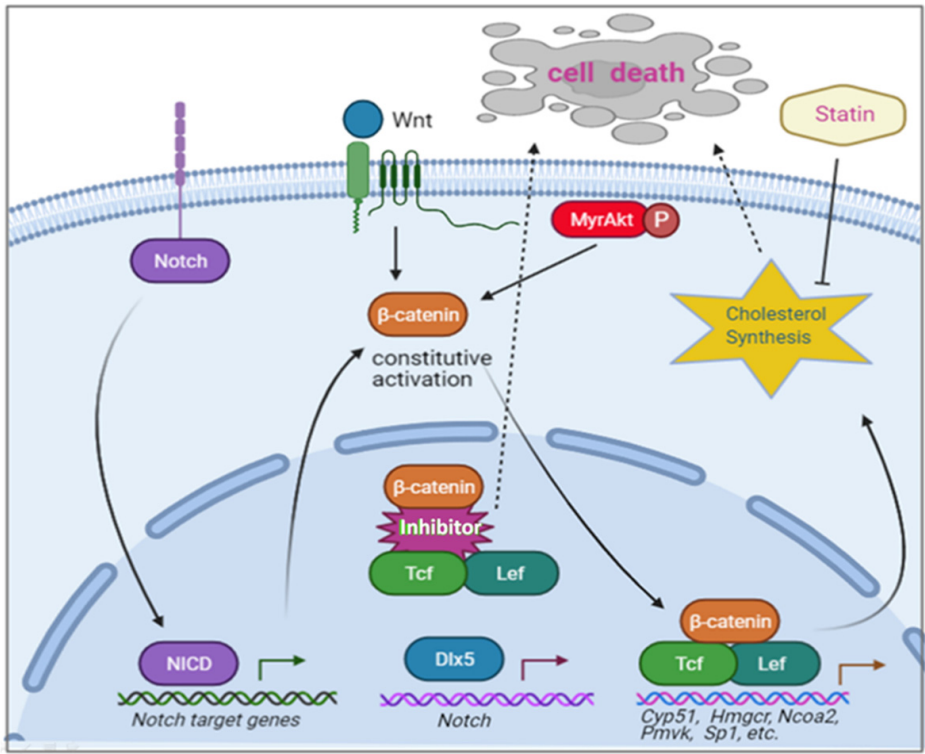

Figure 7. Dlx5 cooperates with activated Akt (MyrAkt) to accelerate T-cell lymphoma in a GEM model. The Wnt pathway was activated when mouse T-cells expressed both Dlx 5 and MyrAkt 2 transgenes. Inhibition of the $\beta$-catenin/Tcf complex resulted in apoptosis. $\beta$-catenin/Tcf directly transactivates several key components in the cholesterol synthesis pathway, such as Cyp51, Hmgcr, and Ncoa2. The augmented cholesterol synthesis at least partially underlies the oncogenic role of Wnt signaling, as statin treatment triggered cell death in these cells. 


\section{Involvement of $D L X$ Genes in Other Malignancies}

Normal cells cannot proliferate infinitely due to telomere erosion, which forces cells to enter a state of replicative senescence by activating ATM/p53 signaling. Interestingly, DLX2 expression has been shown to result in a prolonged replicative life span by diminishing protein components of the TTI1/TTI2/TEL2 complex [68]. This complex is essential for the proper folding and stabilization of ATM and other members of the PI3K-related kinase family kinase (PIKK), resulting in weakened ATM/p53 signaling and senescence bypass. The investigators also found that overexpression of DLX2 displayed a mutually exclusive relationship with p53 defects in cancer patients [68]. In related work, Yilmaz and colleagues have shown that DLX2 protect against transforming growth factor $\beta$ (TGF $\beta$ )-induced cellcycle arrest and apoptosis [69]. TGF $\beta$ acts as a tumor suppressor by inhibiting cell cycle progression during the early stages of carcinogenesis, whereas it shows tumor promoting activity at later stages. The investigators found that Dlx2 exerted important functions in flipping this switch, doing so in part by directly suppressing the transcription of TGF $\beta$ receptor II and the cell cycle inhibitor p21 (CDKN1A), diminishing SMAD signaling, enhancing c-MYC transcription, and increasing EGFR signaling. Dlx2 expression was also found to promote tumor invasion and metastasis [69].

TGF $\beta$ signaling is known to induce epithelial to mesenchymal transition (EMT) via upregulation of SNAIL [70]. Moreover, overexpression of Dlx2 induces the expression of SNAIL, and knockdown of Dlx2 blocks TGF $\beta$-induced EMT [71]. Dlx2 also induces the expression of the glutamine metabolism enzyme glutaminase (GLS1), and knockdown of $D l x 2$ reduces glutamine metabolism, which results in SNAIL expression [72]. In glioblastoma multiforme (GBM) patients, high levels of DLX2 have been associated with a poor survival outlook, and knockdown of DLX2 in GBM cells reduced cyclin D1 expression [73]. However, the role of DLX2 appears to be cancer-type dependent. For example, during glucose deprivation-driven metabolic stress in breast cancer cells, DLX2 was induced by reactive oxygen species, and knockdown of DLX2 protected cells from necrosis [74]. Moreover, expression of DLX2 and DLX5 have been reported to be mutually exclusive in breast cancer, with DLX2 expression being significantly correlated with a favorable prognosis, whereas DLX5 was associated with metastasis [75].

DLX4 is also involved in switching TGF $\beta$ signaling from tumor suppressing to tumor promoting. DLX4 has been shown to inhibit TGF $\beta$-induced expression of p15(Ink4b) and p21 by binding to and inhibiting Smad4 from forming complexes with Smad2 and Smad3 [76]. Moreover, the same investigation revealed that expression of DLX4 stimulated the expression of c-Myc independently of TGF $\beta$ /Smad signaling. In breast cancer, patients whose tumors express high levels of DLX4 respond poorly to topoisomerase II (TOP2)targeting chemotherapy, which kills tumor cells by inducing DNA double-strand breaks (DSB) [77]. Mechanistically, DLX4 was found to interact with Ku proteins to promote DNA-dependent protein kinase activity and end-joining repair of DSBs, thereby, reducing sensitivity of tumor cells to TOP2 poisons. In other work, DLX4 was shown to promote EMT in breast cancer cells through TWIST [78]. DLX4 directly bound to the TWIST gene promoter to regulate its expression, and DLX4 overexpression enhanced expression of TWIST. Furthermore, knockdown of DLX4 decreased TWIST expression, resulting in reduced migration ability of breast cancer cell lines. In one study, the gene copy number of DLX4 was elevated in about $22 \%$ of primary breast cancer and $24 \%$ of the cancers with sentinel lymph node (SLN) metastasis [79]. DLX4 has also been documented to promote expression of iNOS via binding to STAT1, and the elevated levels of this enzyme triggered angiogenesis by producing nitric oxide [80]. High DLX4 expression in ovarian cancer strongly correlated with elevated levels of iNOS and poor survival. Furthermore, expression of DLX4 in ovarian cancer cells potentiated endothelial cell proliferation in vitro and microvessel formation in xenograft tumors [80]. DLX4 also induced the expression of CD44 in ovarian cancer cells, and inhibition of CD44 abolished DLX4's ability of DLX4 to promote tumor-mesothelial cell interactions in these cells [81]. Induction of CD44 
by DLX4 was connected with enhanced NF-KB activity, which was stimulated by IL-1 $\beta$, a transcriptional target of DLX4.

The MYC gene has been shown to be a transcriptional target of DLX5 [82]. DLX5 binds to the MYC promoter and activates MYC expression in vitro, as shown by a MYC promoter assay in HEK 293 cells. Moreover, overexpression of DLX5 results in increased cell proliferation by upregulating MYC. In a screen of the NCI 60 cancer cell line panel, DLX5 was frequently upregulated in cell lines derived from several tumor types, including ovarian cancer [83], and data from The Cancer Genome Atlas indicate that DLX5 is a poor prognosis marker in ovarian cancer (Figure 8). We found that overexpression of DLX5 promoted ovarian cancer cell proliferation by augmenting IRS-2/AKT signaling [83]. DLX5 potentiated AKT signaling to promote tumor cell proliferation, and knockdown of DLX5 reduced cell viability and downregulated IRS-2 and AKT phosphorylation. Moreover, DLX5 was found to directly bind the IRS2 promoter and regulate IRS2 expression (Figure 9) [83].

\section{Kaplan Meier gene expression RNAseq - HTSeq - FPKM-UQ}

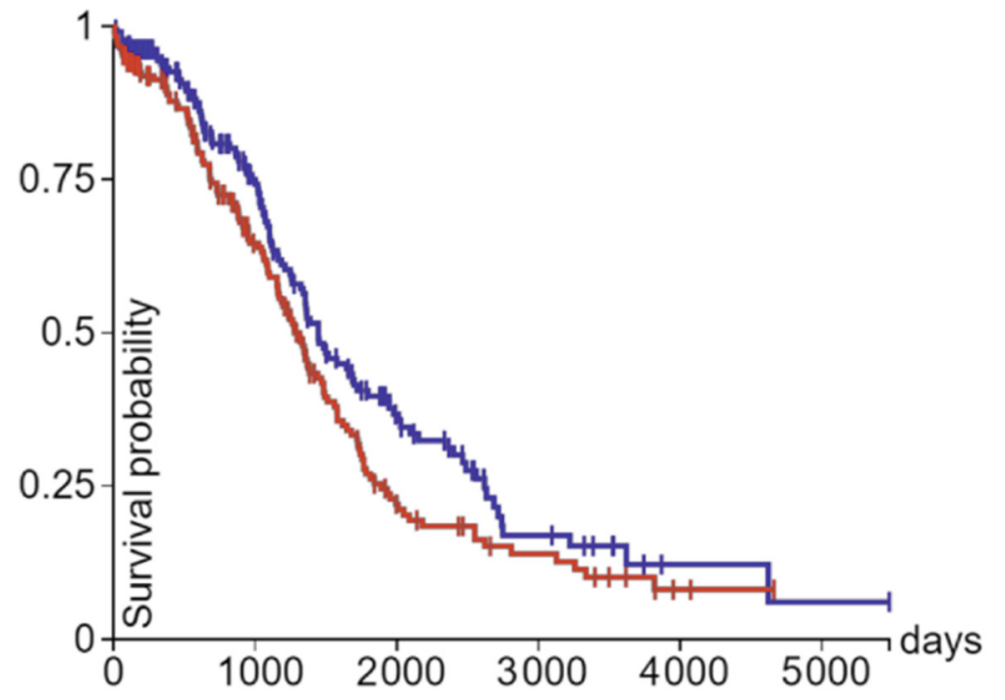

\section{$D L X 5$}

$P$-value $=0.0394$

Log-ranktest statistics $=4.243$

\section{At risk}

$D L X 5$

$\begin{array}{lllllll}189 & 89 & 35 & 11 & 2 & 1 & -<13.71(n=198) \\ 189 & 94 & 25 & 11 & 2 & 0 & ->=13.71(n=189)\end{array}$

Figure 8. DLX5 is a poor prognosis marker in ovarian cancer. The RNA expression level of DLX5 in The Cancer Genome Atlas (TCGA) indicate that higher expression of DLX5 transcripts is associated with poorer survival in ovarian patients. HTSeqFPKM-UQ = High Throughput Sequencing-Fragments Per Kilobase of transcript per Million mapped reads-Upper Quartile.

DLX5 and other homeobox genes such as HOXA have been shown to be methylated in early stage lung cancers [84]. In a study of human non-small cell lung cancer (NSCLC), DLX5 was determined to be activated by KDM4A-mediated demethylation, and in turn, DLX5 induced the expression of MYC and $\beta$-catenin, thereby, promoting proliferation and metastasis [85]. Kato et al. found that the expression level of DLX5 protein significantly correlated with tumor size and poorer prognosis in NSCLC patients [86]. Moreover, knockdown of DLX5 with small interfering RNAs markedly suppressed the proliferation of NSCLC cells [86]. The homeobox genes DLX2, DLX5, and HOXB2 were each overexpressed in a subgroup of small cell lung cancer cell lines [87]. In endometrial carcinomas, DLX5 was upregulated in tumors of the endometrioid subtype, but not in those with papillary serous features [88]. Recently, miRNA have been implicated in regulating DLX gene function in carcinogenesis. For example, in prostate cancer, miR-489-3p directly targets DLX1 and downregulates its expression; overexpression of miR-489-3p was shown to induce apopto- 
sis [89]. In hepatocellular carcinoma, miR-122 was reported to be downregulated; miR-122 was able to bind to the $3^{\prime} \mathrm{UTR}$ of DLX4 mRNA, resulting in down regulated expression of DLX4 protein [90].

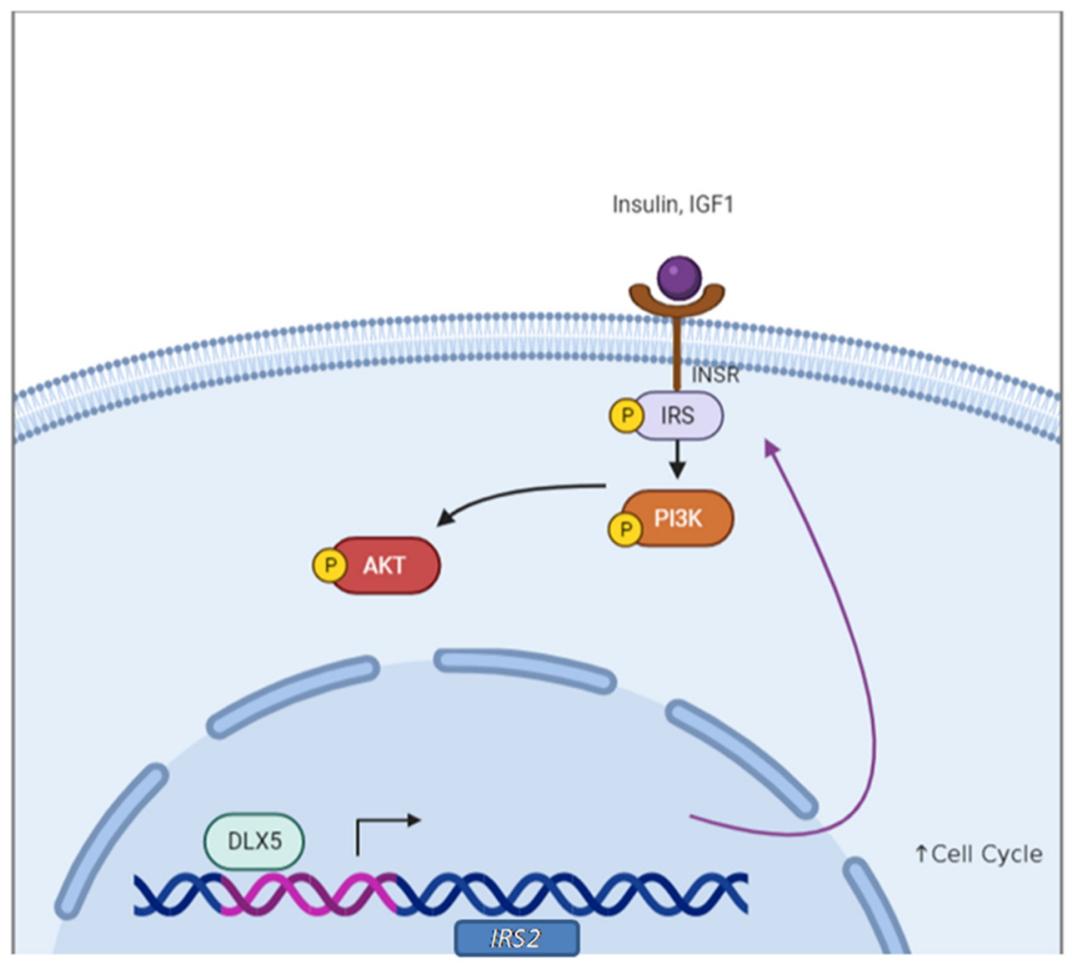

Figure 9. DLX5 upregulates IRS2 expression to enhance AKT signaling. In human ovarian cancer, DLX5 can directly bind to the IRS2 promoter and increase its expression. The resulting elevated IRS2 levels, in turn, augment AKT signaling, which is essential for tumor cell survival.

\section{Conclusions}

The Antennapedia (ANTP) class makes up the largest of the homeobox gene classes in animal genomes [2]. Hox and ANTP-like homeobox gene classes play key roles in the development of bilaterians, animals with bilateral symmetry as an embryo. This gene group was fundamental to the origin of metazoan life on earth [91]. As a subgroup of such ancient master regulators, DLX homeobox family genes play important roles not only in embryogenesis primarily involving neuronal differentiation, cranial and limb development, but also in postnatal homeostasis, such as hematopoiesis and, when dysregulated, oncogenesis. DLX family members are implicated in crosstalk with other signaling and developmental pathways in tissue specific microenvironments. Disturbances of DLX proteins by genomic alterations either at the enhancer level or within the coding region result in congenital disorders such as tricho-dento-osseous syndrome and split-hand/foot malformation. Dysregulation of DLX gene expression is also involved in various types of cancers, including leukemias and lymphomas. With a deeper understanding of DLX's role in human disease, future therapeutic approaches aimed at correcting aberrant $D L X$ gene expression, via pharmacological or biological means, hold promise for alleviating these diseases.

Author Contributions: Original draft preparation, Y.T.; figures, Y.T.; writing review, J.R.T.; editing, J.R.T. All authors have read and agreed to the published version of the manuscript.

Funding: Supported in part by the grant P30 CA006927/CA/NCI NIH HHS/United States and R01 CA077429/CA/NCI NIH HHS/United States. Original research reviewed here by the Testa laboratory was supported by the R01 CA077429.

Institutional Review Board Statement: Not applicable. 
Informed Consent Statement: Not applicable.

Data Availability Statement: Not applicable.

Conflicts of Interest: The authors declare no conflict of interest related to this work.

\section{References}

1. Gehring, W.J. Homeo boxes in the study of development. Science 1987, 236, 1245-1252. [CrossRef]

2. Holland, P.W. Evolution of homeobox genes. Wiley Interdiscip. Rev. Dev. Biol. 2013, 2, 31-45. [CrossRef]

3. Burglin, T.R.; Affolter, M. Homeodomain proteins: An update. Chromosoma 2016, 125, 497-521. [CrossRef] [PubMed]

4. Gehring, W.J.; Affolter, M.; Burglin, T. Homeodomain proteins. Annu. Rev. Biochem. 1994, 63, 487-526. [CrossRef]

5. Gehring, W.J.; Muller, M.; Affolter, M.; Percival-Smith, A.; Billeter, M.; Qian, Y.Q.; Otting, G.; Wuthrich, K. The structure of the homeodomain and its functional implications. Trends Genet. 1990, 6, 323-329. [CrossRef]

6. Scott, M.P.; Tamkun, J.W.; Hartzell, G.W., 3rd. The structure and function of the homeodomain. Biochim. Biophys. Acta 1989, 989, 25-48. [CrossRef]

7. Luke, G.N.; Castro, L.F.; McLay, K.; Bird, C.; Coulson, A.; Holland, P.W. Dispersal of NK homeobox gene clusters in amphioxus and humans. Proc. Natl. Acad. Sci. USA 2003, 100, 5292-5295. [CrossRef]

8. Homminga, I.; Pieters, R.; Meijerink, J.P. NKL homeobox genes in leukemia. Leukemia 2012, 26, 572-581. [CrossRef]

9. Holland, P.W.; Booth, H.A.; Bruford, E.A. Classification and nomenclature of all human homeobox genes. BMC Biol. 2007, 5, 47. [CrossRef] [PubMed]

10. Nagel, S.; Venturini, L.; Przybylski, G.K.; Grabarczyk, P.; Meyer, C.; Kaufmann, M.; Battmer, K.; Schmidt, C.A.; Drexler, H.G.; Scherr, M.; et al. NK-like homeodomain proteins activate NOTCH3-signaling in leukemic T-cells. BMC Cancer $2009,9,371$. [CrossRef]

11. Cohen, S.M.; Bronner, G.; Kuttner, F.; Jurgens, G.; Jackle, H. Distal-less encodes a homoeodomain protein required for limb development in Drosophila. Nature 1989, 338, 432-434. [CrossRef]

12. Depew, M.J.; Liu, J.K.; Long, J.E.; Presley, R.; Meneses, J.J.; Pedersen, R.A.; Rubenstein, J.L. Dlx5 regulates regional development of the branchial arches and sensory capsules. Development 1999, 126, 3831-3846. [CrossRef] [PubMed]

13. Sumiyama, K.; Irvine, S.Q.; Stock, D.W.; Weiss, K.M.; Kawasaki, K.; Shimizu, N.; Shashikant, C.S.; Miller, W.; Ruddle, F.H. Genomic structure and functional control of the Dlx3-7 bigene cluster. Proc. Natl. Acad. Sci. USA 2002, 99, 780-785. [CrossRef]

14. Poitras, L.; Ghanem, N.; Hatch, G.; Ekker, M. The proneural determinant MASH1 regulates forebrain Dlx1/2 expression through the I12b intergenic enhancer. Development 2007, 134, 1755-1765. [CrossRef] [PubMed]

15. Ghanem, N.; Yu, M.; Long, J.; Hatch, G.; Rubenstein, J.L.; Ekker, M. Distinct cis-regulatory elements from the Dlx1/Dlx2 locus mark different progenitor cell populations in the ganglionic eminences and different subtypes of adult cortical interneurons. J. Neurosci. 2007, 27, 5012-5022. [CrossRef]

16. Ghanem, N.; Jarinova, O.; Amores, A.; Long, Q.; Hatch, G.; Park, B.K.; Rubenstein, J.L.; Ekker, M. Regulatory roles of conserved intergenic domains in vertebrate $D l x$ bigene clusters. Genome Res. 2003, 13, 533-543. [CrossRef]

17. Sumiyama, K.; Irvine, S.Q.; Ruddle, F.H.. The role of gene duplication in the evolution and function of the vertebrate $D l x /$ distalless bigene clusters. J. Struct. Funct. Genomics 2003, 3, 151-159. [CrossRef]

18. Sumiyama, K.; Ruddle, F.H. Regulation of $D l x 3$ gene expression in visceral arches by evolutionarily conserved enhancer elements. Proc. Natl. Acad. Sci. USA 2003, 100, 4030-4034. [CrossRef] [PubMed]

19. Stock, D.W.; Ellies, D.L.; Zhao, Z.; Ekker, M.; Ruddle, F.H.; Weiss, K.M. The evolution of the vertebrate Dlx gene family. Proc. Natl. Acad. Sci. USA 1996, 93, 10858-10863. [CrossRef]

20. Pollard, S.L.; Holland, P.W. Evidence for 14 homeobox gene clusters in human genome ancestry. Curr. Biol. 2000, 10, 1059-1062. [CrossRef]

21. Park, B.K.; Sperber, S.M.; Choudhury, A.; Ghanem, N.; Hatch, G.T.; Sharpe, P.T.; Thomas, B.L.; Ekker, M. Intergenic enhancers with distinct activities regulate Dlx gene expression in the mesenchyme of the branchial arches. Dev. Biol. 2004, 268, 532-545. [CrossRef] [PubMed]

22. Ruest, L.B.; Hammer, R.E.; Yanagisawa, M.; Clouthier, D.E. Dlx5/6-enhancer directed expression of Cre recombinase in the pharyngeal arches and brain. Genesis 2003, 37, 188-194. [CrossRef]

23. Ellies, D.L.; Stock, D.W.; Hatch, G.; Giroux, G.; Weiss, K.M.; Ekker, M. Relationship between the genomic organization and the overlapping embryonic expression patterns of the zebrafish dlx genes. Genomics 1997, 45, 580-590. [CrossRef]

24. Zerucha, T.; Ekker, M. Distal-less-related homeobox genes of vertebrates: Evolution, function, and regulation. Biochem. Cell Biol. 2000, 78, 593-601. [CrossRef]

25. Qiu, M.; Bulfone, A.; Ghattas, I.; Meneses, J.J.; Christensen, L.; Sharpe, P.T.; Presley, R.; Pedersen, R.A.; Rubenstein, J.L. Role of the Dlx homeobox genes in proximodistal patterning of the branchial arches: Mutations of Dlx-1, Dlx-2, and Dlx-1 and -2 alter morphogenesis of proximal skeletal and soft tissue structures derived from the first and second arches. Dev. Biol. 1997, 185, 165-184. [CrossRef]

26. Qiu, M.; Bulfone, A.; Martinez, S.; Meneses, J.J.; Shimamura, K.; Pedersen, R.A.; Rubenstein, J.L. Null mutation of Dlx-2 results in abnormal morphogenesis of proximal first and second branchial arch derivatives and abnormal differentiation in the forebrain. Genes. Dev. 1995, 9, 2523-2538. [CrossRef] 
27. Anderson, S.A.; Qiu, M.; Bulfone, A.; Eisenstat, D.D.; Meneses, J.; Pedersen, R.; Rubenstein, J.L. Mutations of the homeobox genes Dlx-1 and Dlx-2 disrupt the striatal subventricular zone and differentiation of late born striatal neurons. Neuron 1997, $19,27-37$. [CrossRef]

28. De Melo, J.; Du, G.; Fonseca, M.; Gillespie, L.A.; Turk, W.J.; Rubenstein, J.L.; Eisenstat, D.D. Dlx1 and Dlx2 function is necessary for terminal differentiation and survival of late-born retinal ganglion cells in the developing mouse retina. Development 2005, 132, 311-322. [CrossRef] [PubMed]

29. Zhou, Q.P.; Le, T.N.; Qiu, X.; Spencer, V.; de Melo, J.; Du, G.; Plews, M.; Fonseca, M.; Sun, J.M.; Davie, J.R.; et al. Identification of a direct Dlx homeodomain target in the developing mouse forebrain and retina by optimization of chromatin immunoprecipitation. Nucleic. Acids Res. 2004, 32, 884-892. [CrossRef] [PubMed]

30. Acampora, D.; Merlo, G.R.; Paleari, L.; Zerega, B.; Postiglione, M.P.; Mantero, S.; Bober, E.; Barbieri, O.; Simeone, A.; Levi, G. Craniofacial, vestibular and bone defects in mice lacking the Distal-less-related gene Dlx5. Development 1999, 126, 3795-3809. [CrossRef] [PubMed]

31. Robledo, R.F.; Rajan, L.; Li, X.; Lufkin, T. The Dlx5 and Dlx6 homeobox genes are essential for craniofacial, axial, and appendicular skeletal development. Genes. Dev. 2002, 16, 1089-1101. [CrossRef] [PubMed]

32. Li, H.; Marijanovic, I.; Kronenberg, M.S.; Erceg, I.; Stover, M.L.; Velonis, D.; Mina, M.; Heinrich, J.G.; Harris, S.E.; Upholt, W.B.; et al. Expression and function of Dlx genes in the osteoblast lineage. Dev. Biol. 2008, 316, 458-470. [CrossRef]

33. Robledo, R.F.; Lufkin, T. Dlx5 and Dlx6 homeobox genes are required for specification of the mammalian vestibular apparatus. Genesis 2006, 44, 425-437. [CrossRef] [PubMed]

34. Lezot, F.; Thomas, B.; Greene, S.R.; Hotton, D.; Yuan, Z.A.; Castaneda, B.; Bolanos, A.; Depew, M.; Sharpe, P.; Gibson, C.W.; et al. Physiological implications of DLX homeoproteins in enamel formation. J. Cell Physiol. 2008, 216, 688-697. [CrossRef]

35. Nishida, H.; Miyagawa, S.; Vieux-Rochas, M.; Morini, M.; Ogino, Y.; Suzuki, K.; Nakagata, N.; Choi, H.S.; Levi, G.; Yamada, G. Positive regulation of steroidogenic acute regulatory protein gene expression through the interaction between Dlx and GATA-4 for testicular steroidogenesis. Endocrinology 2008, 149, 2090-2097. [CrossRef]

36. Verzi, M.P.; Agarwal, P.; Brown, C.; McCulley, D.J.; Schwarz, J.J.; Black, B.L. The transcription factor MEF2C is required for craniofacial development. Dev. Cell 2007, 12, 645-652. [CrossRef]

37. Lo Iacono, N.; Mantero, S.; Chiarelli, A.; Garcia, E.; Mills, A.A.; Morasso, M.I.; Costanzo, A.; Levi, G.; Guerrini, L.; Merlo, G.R. Regulation of Dlx5 and Dlx6 gene expression by p63 is involved in EEC and SHFM congenital limb defects. Development 2008, 135, 1377-1388. [CrossRef] [PubMed]

38. Brown, K.K.; Reiss, J.A.; Crow, K.; Ferguson, H.L.; Kelly, C.; Fritzsch, B.; Morton, C.C. Deletion of an enhancer near DLX5 and DLX6 in a family with hearing loss, craniofacial defects, and an inv(7)(q21.3q35). Hum. Genet. 2010, 127, 19-31. [CrossRef]

39. Radoja, N.; Guerrini, L.; Lo Iacono, N.; Merlo, G.R.; Costanzo, A.; Weinberg, W.C.; La Mantia, G.; Calabrò, V.; Morasso, M.I. Homeobox gene $D l x 3$ is regulated by p63 during ectoderm development: Relevance in the pathogenesis of ectodermal dysplasias. Development 2007, 134, 13-18. [CrossRef]

40. Isaac, J.; Erthal, J.; Gordon, J.; Duverger, O.; Sun, H.W.; Lichtler, A.C.; Stein, G.S.; Lian, J.B.; Morasso, M.I. DLX3 regulates bone mass by targeting genes supporting osteoblast differentiation and mineral homeostasis in vivo. Cell Death. Differ. 2014, 21, 1365-1376. [CrossRef]

41. Artigas, N.; Gamez, B.; Cubillos-Rojas, M.; Sanchez-de Diego, C.; Valer, J.A.; Pons, G.; Rosa, J.L.; Ventura, F. p53 inhibits SP7/Osterix activity in the transcriptional program of osteoblast differentiation. Cell Death. Differ. 2017, 24, 2022-2031. [CrossRef] [PubMed]

42. Choi, S.J.; Roodman, G.D.; Feng, J.Q.; Song, I.S.; Amin, K.; Hart, P.S.; Wright, J.T.; Haruyama, N.; Hart, T.C. In vivo impact of a 4 bp deletion mutation in the DLX3 gene on bone development. Dev. Biol. 2009, 325, 129-137. [CrossRef]

43. Wu, D.; Mandal, S.; Choi, A.; Anderson, A.; Prochazkova, M.; Perry, H.; Gil-Da-Silva-Lopes, V.L.; Lao, R.; Wan, E.; Tang, P.L.; et al. DLX4 is associated with orofacial clefting and abnormal jaw development. Hum. Mol. Genet. 2015, 24, 4340-4352. [CrossRef] [PubMed]

44. Cui, H.; Han, G.; Sun, B.; Fang, X.; Dai, X.; Zhou, S.; Mao, H.; Wang, B. Activating PIK3CA mutation promotes osteogenesis of bone marrow mesenchymal stem cells in macrodactyly. Cell Death. Dis. 2020, 11, 505. [CrossRef] [PubMed]

45. Twomey-Kozak, J.; Desai, S.; Liu, W.; Li, N.Y.; Lemme, N.; Chen, Q.; Owens, B.D.; Jayasuriya, C.T. Distal-less homeobox 5 is a therapeutic target for attenuating hypertrophy and apoptosis of mesenchymal progenitor cells. Int. J. Mol. Sci. 2020, 21, 4823. [CrossRef]

46. Tamaoki, N.; Takahashi, K.; Aoki, H.; Iida, K.; Kawaguchi, T.; Hatakeyama, D.; Inden, M.; Chosa, N.; Ishisaki, A.; Kunisada, T.; et al. The homeobox gene DLX4 promotes generation of human induced pluripotent stem cells. Sci. Rep. 2014, 4, 7283. [CrossRef]

47. Nardelli, J.; Thiesson, D.; Fujiwara, Y.; Tsai, F.Y.; Orkin, S.H. Expression and genetic interaction of transcription factors GATA-2 and GATA-3 during development of the mouse central nervous system. Dev. Biol. 1999, 210, 305-321. [CrossRef] [PubMed]

48. Huber, T.L.; Zhou, Y.; Mead, P.E.; Zon, L.I. Cooperative effects of growth factors involved in the induction of hematopoietic mesoderm. Blood 1998, 92, 4128-4137. [CrossRef] [PubMed]

49. Li, F.; Lu, S.; Vida, L.; Thomson, J.A.; Honig, G.R. Bone morphogenetic protein 4 induces efficient hematopoietic differentiation of rhesus monkey embryonic stem cells in vitro. Blood 2001, 98, 335-342. [CrossRef] 
50. Chiba, S.; Takeshita, K.; Imai, Y.; Kumano, K.; Kurokawa, M.; Masuda, S.; Shimizu, K.; Nakamura, S.; Ruddle, F.H.; Hirai, H. Homeoprotein DLX-1 interacts with Smad4 and blocks a signaling pathway from activin A in hematopoietic cells. Proc. Natl. Acad. Sci. USA 2003, 100, 15577-15582. [CrossRef]

51. Woodside, K.J.; Shen, H.; Muntzel, C.; Daller, J.A.; Sommers, C.L.; Love, P.E. Expression of Dlx and Lhx family homeobox genes in fetal thymus and thymocytes. Gene Expr. Patterns 2004, 4, 315-320. [CrossRef]

52. Sunwoo, J.B.; Kim, S.; Yang, L.; Naik, T.; Higuchi, D.A.; Rubenstein, J.L.; Yokoyama, W.M. Distal-less homeobox transcription factors regulate development and maturation of natural killer cells. Proc. Natl. Acad. Sci. USA 2008, 105, 10877-10882. [CrossRef] [PubMed]

53. Shin, J.H.; Haggadone, M.D.; Sunwoo, J.B. Transcription factor Dlx3 induces aryl hydrocarbon receptor promoter activity. Biochem. Biophys. Rep. 2016, 7, 353-360. [CrossRef] [PubMed]

54. Shimamoto, T.; Nakamura, S.; Bollekens, J.; Ruddle, F.H.; Takeshita, K. Inhibition of DLX-7 homeobox gene causes decreased expression of GATA-1 and c-myc genes and apoptosis. Proc. Natl. Acad. Sci. USA 1997, 94, 3245-3249. [CrossRef] [PubMed]

55. Trinh, B.Q.; Barengo, N.; Kim, S.B.; Lee, J.S.; Zweidler-McKay, P.A.; Naora, H. The homeobox gene DLX4 regulates erythromegakaryocytic differentiation by stimulating IL-1beta and NF-kappaB signaling. J. Cell Sci. 2015, 128, 3055-3067. [CrossRef] [PubMed]

56. Nagel, S.; Pommerenke, C.; Meyer, C.; Kaufmann, M.; MacLeod, R.A.F.; Drexler, H.G. NKL homeobox gene MSX1 acts like a tumor suppressor in NK-cell leukemia. Oncotarget 2017, 8, 66815-66832. [CrossRef]

57. Nagel, S.; Pommerenke, C.; Scherr, M.; Meyer, C.; Kaufmann, M.; Battmer, K.; MacLeod, R.A.; Drexler, H.G. NKL homeobox gene activities in hematopoietic stem cells, T-cell development and T-cell leukemia. PLoS ONE 2017, 12, e0171164. [CrossRef] [PubMed]

58. Starkova, J.; Gadgil, S.; Qiu, Y.H.; Zhang, N.; Hermanova, I.; Kornblau, S.M.; Drabkin, H.A. Up-regulation of homeodomain genes, DLX1 and DLX2, by FLT3 signaling. Haematologica 2011, 96, 820-828. [CrossRef]

59. Ferrari, N.; Palmisano, G.L.; Paleari, L.; Basso, G.; Mangioni, M.; Fidanza, V.; Albini, A.; Croce, C.M.; Levi, G.; Brigati, C. DLX genes as targets of ALL-1: DLX 2,3,4 down-regulation in $\mathrm{t}(4 ; 11)$ acute lymphoblastic leukemias. J. Leukoc. Biol. 2003, 74, 302-305. [CrossRef]

60. Campo Dell'Orto, M.; Banelli, B.; Giarin, E.; Accordi, B.; Trentin, L.; Romani, M.; te Kronnie, G.; Basso, G. Down-regulation of DLX3 expression in MLL-AF4 childhood lymphoblastic leukemias is mediated by promoter region hypermethylation. Oncol. Rep. 2007, 18, 417-423. [CrossRef]

61. Zhang, T.J.; Xu, Z.J.; Gu, Y.; Wen, X.M.; Ma, J.C.; Zhang, W.; Deng, Z.Q.; Leng, J.Y.; Qian, J.; Lin, J.; et al. Identification and validation of prognosis-related DLX5 methylation as an epigenetic driver in myeloid neoplasms. Clin. Transl. Med. 2020, 10, e29. [CrossRef]

62. Tan, Y.; Timakhov, R.A.; Rao, M.; Altomare, D.A.; Xu, J.; Liu, Z.; Gao, Q.; Jhanwar, S.C.; Di Cristofano, A.; Wiest, D.L.; et al. A novel recurrent chromosomal inversion implicates the homeobox gene Dlx5 in T-cell lymphomas from Lck-Akt2 transgenic mice. Cancer Res. 2008, 68, 1296-1302. [CrossRef]

63. Tan, Y.; Sementino, E.; Xu, J.; Pei, J.; Liu, Z.; Ito, T.K.; Cai, K.Q.; Peri, S.; Klein-Szanto, A.J.; Wiest, D.L.; et al. The homeoprotein Dlx5 drives murine T-cell lymphomagenesis by directly transactivating Notch and upregulating Akt signaling. Oncotarget 2017, 8, 14941-14956. [CrossRef] [PubMed]

64. Tan, Y.; Sementino, E.; Pei, J.; Kadariya, Y.; Ito, T.K.; Testa, J.R. Co-targeting of Akt and Myc inhibits viability of lymphoma cells from Lck-Dlx5 mice. Cancer Biol. Ther. 2015, 16, 580-588. [CrossRef] [PubMed]

65. Ng, O.H.; Erbilgin, Y.; Firtina, S.; Celkan, T.; Karakas, Z.; Aydogan, G.; Turkkan, E.; Yildirmak, Y.; Timur, C.; Zengin, E.; et al. Deregulated WNT signaling in childhood T-cell acute lymphoblastic leukemia. Blood Cancer J. 2014, 4, e192. [CrossRef] [PubMed]

66. Guo, Z.; Dose, M.; Kovalovsky, D.; Chang, R.; O’Neil, J.; Look, A.T.; von Boehmer, H.; Khazaie, K.; Gounari, F. Beta-catenin stabilization stalls the transition from double-positive to single-positive stage and predisposes thymocytes to malignant transformation. Blood 2007, 109, 5463-5472. [CrossRef] [PubMed]

67. Tan, Y.; Sementino, E.; Liu, Z.; Cai, K.Q.; Testa, J.R. Wnt signaling mediates oncogenic synergy between Akt and Dlx5 in T-cell lymphomagenesis by enhancing cholesterol synthesis. Sci. Rep. 2020, 10, 15837. [CrossRef]

68. Wang, Y.; Xu, Q.; Sack, L.; Kang, C.; Elledge, S.J. A gain-of-function senescence bypass screen identifies the homeobox transcription factor DLX2 as a regulator of ATM-p53 signaling. Genes Dev. 2016, 30, 293-306. [CrossRef]

69. Yilmaz, M.; Maass, D.; Tiwari, N.; Waldmeier, L.; Schmidt, P.; Lehembre, F.; Christofori, G. Transcription factor Dlx2 protects from TGFbeta-induced cell-cycle arrest and apoptosis. EMBO J. 2011, 30, 4489-4499. [CrossRef]

70. Nieto, M.A. The snail superfamily of zinc-finger transcription factors. Nat. Rev. Mol. Cell Biol. 2002, 3, 155-166. [CrossRef] [PubMed]

71. Lee, S.Y.; Jeon, H.M.; Ju, M.K.; Jeong, E.K.; Kim, C.H.; Yoo, M.A.; Park, H.G.; Han, S.I.; Kang, H.S. Dlx-2 is implicated in TGF-betaand Wnt-induced epithelial-mesenchymal, glycolytic switch, and mitochondrial repression by Snail activation. Int. J. Oncol. 2015, 46, 1768-1780. [CrossRef] [PubMed]

72. Lee, S.Y.; Jeon, H.M.; Ju, M.K.; Jeong, E.K.; Kim, C.H.; Park, H.G.; Han, S.I.; Kang, H.S. Dlx-2 and glutaminase upregulate epithelial-mesenchymal transition and glycolytic switch. Oncotarget 2016, 7, 7925-7939. [CrossRef] [PubMed]

73. Yan, Z.H.; Bao, Z.S.; Yan, W.; Liu, Y.W.; Zhang, C.B.; Wang, H.J.; Feng, Y.; Wang, Y.Z.; Zhang, W.; You, G.; et al. Upregulation of DLX2 confers a poor prognosis in glioblastoma patients by inducing a proliferative phenotype. Curr. Mol. Med. 2013, 13, 438-445. 
74. Lee, S.Y.; Jeon, H.M.; Kim, C.H.; Ju, M.K.; Bae, H.S.; Park, H.G.; Lim, S.C.; Han, S.I.; Kang, H.S. Homeobox gene Dlx-2 is implicated in metabolic stress-induced necrosis. Mol. Cancer 2011, 10, 113. [CrossRef] [PubMed]

75. Morini, M.; Astigiano, S.; Gitton, Y.; Emionite, L.; Mirisola, V.; Levi, G.; Barbieri, O. Mutually exclusive expression of DLX2 and DLX5/6 is associated with the metastatic potential of the human breast cancer cell line MDA-MB-231. BMC Cancer 2010, 10, 649. [CrossRef] [PubMed]

76. Trinh, B.Q.; Barengo, N.; Naora, H. Homeodomain protein DLX4 counteracts key transcriptional control mechanisms of the TGF-beta cytostatic program and blocks the antiproliferative effect of TGF-beta. Oncogene 2011, 30, 2718-2729. [CrossRef]

77. Trinh, B.Q.; Ko, S.Y.; Barengo, N.; Lin, S.Y.; Naora, H. Dual functions of the homeoprotein DLX4 in modulating responsiveness of tumor cells to topoisomerase II-targeting drugs. Cancer Res. 2013, 73, 1000-1010. [CrossRef]

78. Zhang, L.; Yang, M.; Gan, L.; He, T.; Xiao, X.; Stewart, M.D.; Liu, X.; Yang, L.; Zhang, T.; Zhao, Y.; et al. DLX4 upregulates TWIST and enhances tumor migration, invasion and metastasis. Int. J. Biol. Sci. 2012, 8, 1178-1187. [CrossRef]

79. Torresan, C.; Oliveira, M.M.; Pereira, S.R.; Ribeiro, E.M.; Marian, C.; Gusev, Y.; Lima, R.S.; Urban, C.A.; Berg, P.E.; Haddad, B.R.; et al. Increased copy number of the DLX4 homeobox gene in breast axillary lymph node metastasis. Cancer Genet. 2014, 207, 177-187. [CrossRef]

80. Trinh, B.; Ko, S.Y.; Haria, D.; Barengo, N.; Naora, H. The homeoprotein DLX4 controls inducible nitric oxide synthase-mediated angiogenesis in ovarian cancer. Mol. Cancer. 2015, 14, 97. [CrossRef]

81. Haria, D.; Trinh, B.Q.; Ko, S.Y.; Barengo, N.; Liu, J.; Naora, H. The homeoprotein DLX4 stimulates NF-kappaB activation and CD44-mediated tumor-mesothelial cell interactions in ovarian cancer. Am. J. Pathol. 2015, 185, 2298-2308. [CrossRef]

82. Xu, J.; Testa, J.R. DLX5 (distal-less homeobox 5) promotes tumor cell proliferation by transcriptionally regulating MYC. J. Biol. Chem. 2009, 284, 20593-20601. [CrossRef] [PubMed]

83. Tan, Y.; Cheung, M.; Pei, J.; Menges, C.W.; Godwin, A.K.; Testa, J.R. Upregulation of DLX5 promotes ovarian cancer cell proliferation by enhancing IRS-2-AKT signaling. Cancer Res. 2010, 70, 9197-9206. [CrossRef] [PubMed]

84. Rauch, T.; Wang, Z.; Zhang, X.; Zhong, X.; Wu, X.; Lau, S.K.; Kernstine, K.H.; Riggs, A.D.; Pfeifer, G.P. Homeobox gene methylation in lung cancer studied by genome-wide analysis with a microarray-based methylated CpG island recovery assay. Proc. Natl. Acad. Sci. USA 2007, 104, 5527-5532. [CrossRef]

85. Sun, S.; Yang, F.; Zhu, Y.; Zhang, S. KDM4A promotes the growth of non-small cell lung cancer by mediating the expression of Myc via DLX5 through the Wnt/beta-catenin signaling pathway. Life Sci. 2020, 262, 118508. [CrossRef]

86. Kato, T.; Sato, N.; Takano, A.; Miyamoto, M.; Nishimura, H.; Tsuchiya, E.; Kondo, S.; Nakamura, Y.; Daigo, Y. Activation of placenta-specific transcription factor distal-less homeobox 5 predicts clinical outcome in primary lung cancer patients. Clin. Cancer Res. 2008, 14, 2363-2370. [CrossRef]

87. Pedersen, N.; Mortensen, S.; Sorensen, S.B.; Pedersen, M.W.; Rieneck, K.; Bovin, L.F.; Poulsen, H.S. Transcriptional gene expression profiling of small cell lung cancer cells. Cancer Res. 2003, 63, 1943-1953. [PubMed]

88. Maxwell, G.L.; Chandramouli, G.V.; Dainty, L.; Litzi, T.J.; Berchuck, A.; Barrett, J.C.; Risinger, J.I. Microarray analysis of endometrial carcinomas and mixed mullerian tumors reveals distinct gene expression profiles associated with different histologic types of uterine cancer. Clin. Cancer Res. 2005, 11, 4056-4066. [CrossRef]

89. Bai, P.; Li, W.; Wan, Z.; Xiao, Y.; Xiao, W.; Wang, X.; Wu, Z.; Zhang, K.; Wang, Y.; Chen, B.; et al. miR-489-3p inhibits prostate cancer progression by targeting DLX1. Cancer Manag. Res. 2020, 12, 2719-2729. [CrossRef]

90. Xie, X.H.; Xu, X.P.; Sun, C.Y.; Yu, Z.J. Regulation of the oncogenic function of distal-less 4 by microRNA-122 in hepatocellular carcinoma. Mol. Med. Rep. 2015, 12, 1375-1380. [CrossRef] [PubMed]

91. Larroux, C.; Fahey, B.; Degnan, S.M.; Adamski, M.; Rokhsar, D.S.; Degnan, B.M. The NK homeobox gene cluster predates the origin of Hox genes. Curr. Biol. 2007, 17, 706-710. [CrossRef] [PubMed] 